\title{
再生骨材・副産物起源骨材の利用における 環境影響評価一土木工事での利用の観点から一
}

堺 孝司*1 ・河合 研至*2

\section{1.はじめに}

世界の物質フローは約 260 億トンとされる ${ }^{1)}$ 。このう ち，建設用骨材が約 200 億トンであり，コンクリートの 生産量が約 94 億トンである ${ }^{2}$ 。つまり，建設分野におい てこれだけ膨大な資源が毎年世界で消費されていること になるが，逆の見方をすればこれだけの資源をストック し続けている, とも言える。人類は近代社会を構築し始 めてからそれほどの歴史を有しておらず，現在地球が抱 える環境問題発生の原点之なった産業革命が起こってか ら 200 年余りに過ぎない。また，コンクリートの歴史は 浅く，これほど大量に用いられ始めたのはせいぜいここ 半世紀のことである。この間先進諸国が基本的なインフ ラをほぼ整備し終わり，今後発展途上国は先進国が歩ん できた道を辿ることになる。

2007 年に IPCC の第 4 次報告書が出された。そこで は，地球温暖化は既に始まっており，その原因は人類の 活動に起因することが明確に述べられているとともに， Sustainable Developmentにより地球温暖化を抑制す ることの重要性が強調されている。このような科学的な 分析評価の結果として, 今後地球温暖化に世界がどう対 応するかということについて国際政治の舞台で様々な駆 け引きが行われるようになっている。このような動きか ら，資源・エネルギー利用による環境影響についての評 価が極めて重要な問題として認識されるようになってき た。あらゆる産業が，自らの生産・経済活動による環境 負荷を低減することが求められ，それがビジネスの中心 になってきた感すらある。

日本に扔ける建設分野は，特に土木の分野でインフラ 成熟による事業量減少に伴い実質的に環境負荷は低減し 続けている。そうであるからと言って，建設分野が環境 負荷低減から免除されるわけではない。また，今後発展 途上国での事業が急増することが考えられる。さらには， 建設リサイクルの推進や天然骨材の枯渇，あるいは産業 副産物の環境の観点からの利用など，建設環境を取り巻

* 1 さかい・こうじ／香川大学工学部安全システム建設工学科（正 会員)

*2 かわい・けんじ/広島大学大学院工学研究科社会環境システム 専攻（正会員）
く社会的状況も大きく変わってきている。いずれにして も，膨大な資源とエネルギーを使用する建設分野におい ては，今後環境を意識した設計・施工・供用・解体・リ サイクルを行っていく必要があることは明らかであるが, 現状はそのような方向に向かった地ならしをしている状 況と言える。したがって，建設・コンクリート分野にお ける環境影響評価は, 振動・騒音など従来の評価範囲に 留まっているのが実態である。そのような中で，コンク リートの分野では土木学会から「コンクリート構造物の 環境性能照査指針 (試案) 」3)が刊行され，我々が目指す ベき 1 つの方向が示された。

このような背景と本特集号の趣旨を踏まえて，本稿で は, 再生骨材之副産物起源骨材の環境影響評価の現状に ついて述べる。また，これと関連して環境配慮を建設事 業に組み込むためのシステムと再生骨材・副産物起源骨 材の利用促進について言及する。

\section{2. 再生骨材}

本特集号において再生骨材製造技術とその実施例につ いて紹介されている。一般に, 解体コンクリートから再 生骨材を製造する際，2つの問題が発生する。1つは, バージン骨材と比べて多くのエネルギーを消費すること であり，他の 1 つはセメント水和物微粉が発生すること である。前者はコスト増と環境負荷に繋がり，後者はそ の処理が大きな問題となる。したがって, 解体コンクリー トのほとんどはクラッシャランとして路盤材に用いられ てきた。これらのことに起因して，再生骨材の実際への 適用は極めて限られている。現在, 日本でよ゙のくらいの 再生骨材がコンクリート用骨材として用いられているか の統計資料は無い。

前述したように，再生骨材の製造はエネルギー使用が 多くなり，したがって環境負荷が大きくなるが，外部コ ストの内部化に加えて，この環境負荷をどのように吸収 するかが，再生骨材利用促進の鍵になる。黒田ら ${ }^{4)}$ は, 加熱すり屯みによる再生骨材の製造に関わる環境負荷を 利用システムをも含めて考慮するために，オンサイト型 コンクリート資源循環システムを構築し，それによる環 境負荷を算定し，解体によって発生したコンクリートが 


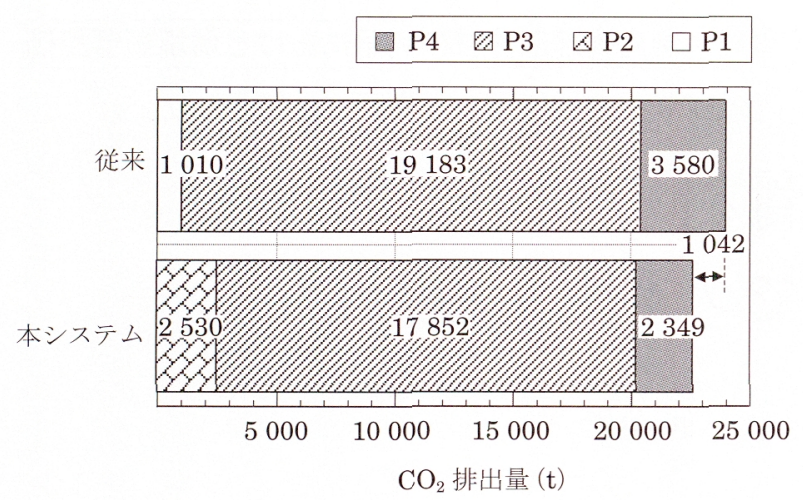

図-1 再生骨材製造・利用による環境負荷 ${ }^{4}$

らを再資源化施設へ輸送して路盤材を製造する場合と比 較した。図-1にその結果を示す。インベントリー分析 は, $\mathrm{CO}_{2}$ 排出量について, 路盤材利用 (P 1), 骨材製造 (P 2)，生コン製造（P 3)，および地盤改良（P 4）につ いて行っている。これによれば，再生骨材製造の $\mathrm{CO}_{2}$ 排出量は, 路盤材製造の 5 倍以上となるが, 輸送や地盤 改良のための固化剂の減少により $\mathrm{CO}_{2}$ が減少した結果, 全体としてオンサイト型コンクリート資源循環システム は，再資源化施設へ輸送して処理するケースより $\mathrm{CO}_{2}$ 排出が約 1000 トン減少した。この例は，1つの技術の 環境負荷を考慮するのではなくシステムとして捉えるこ との重要性を示した。

柳橋5) は, 解体後のコンクリート塊を破砕処理して路 盤材に利用し，コンクリートを天然の骨材で製造するケー ス（ケース 1), 解体後のコンクリート塊を高度処理し てコンクリート用再生粗骨材を製造して利用するケース (ケース 2), 解体後のコンクリート塊を高度処理してコ ンクリート用再生粗骨材を製造し，さらに細粒分をセメ ントクリンカー原料に利用するケース（ケース 3）につ いての $\mathrm{CO}_{2}$ 排出量を算定し, 各ケースの $\mathrm{CO}_{2}$ 排出量は ほぼ同じとなることを示した。換言すれば，この場合， 再生粗骨材の利用は天然骨材資源の保存に寄与すること を意味する。

上述した $2 つ の$ 例は, 再生骨材の環境負荷が，再生骨 材製造技術のエネルギー消費や製造によって発生する副 産物の処理に大きく影響されることを示しており, 今後 の再生骨材製造技術開発の方向性を明確にしている。

間断なく建造されるコンクリート構造物のストックは, 将来の潜在資源である。すなわち, 解体コンクリート塊 は, 天然骨材保存の貴重な資源と考える必要がある。そ のためにはこれを最も良い形で利用することが重要であ る。そのような意味において, 現在行われている路盤材 としての利用は, 必ずしも資源利用効率がいいとは言い 難い。再生骨材の利用促進を図るためには, 製造技術の 高度化や微粉の利用などにおいて環境負荷を最小化する ことが大きな命題になる。また, セメント水和物の微粉 は $\mathrm{CO}_{2}$ 吸収源として機能する。つまり,これをセメン 卜製造の原料に用いれば，セメント製造の石灰石資源保
存効果と $\mathrm{CO}_{2}$ 排出原単位低減に寄与することになる。 今後, 再生骨材製造の際に発生する微粉の $\mathrm{CO}_{2}$ 吸收量 上, これらのセメントへの利用効果に関する検討が必要 である。

\section{3. 副産物起源骨材}

コンクリートには従来から産業副産物である各種混和 材を用いてきた。その主な目的は，産業副産物の有効利 用㧍よびコンクリートの性能改善であった。しかし，近 年, これらに加えて環境の観点加ら混和材を積極的に利 用しようとする考え方が生まれている。Malhotra ${ }^{6)}$ は, 長い間フライアッシュをセメント代替として大量に使用 してコンクリートの $\mathrm{CO}_{2}$ 排出量を削減することを提案 してきた。しかしながら，世界的にそのような利用法が 普及する状況にはない。その主な理由は, フライアッシュ のポゾラン反応性は多様であり，コンクリートの性能が 大きく異なる可能性があることなどが考えられる。

図-2に，日本に扮ける2005 年度のフライアッシュ利 用量 1067 万トンの利用内訳”を示す。セメント分野利 用のほとんどがセメント原材料として用いられている現 状にある。フライアッシュ生産量の $20 \%$ 程度がコンク リートへ利用できるとされているが，混和材としての利 用は $1 \%$ 以下であり，この現状は必ずし屯適切とは言え ない。

世界のフライアッシュの生産量は現在 3 億トンを超え, 2020 年には 5 億トンに達すると予測されている ${ }^{8)}$ 。これ らをセメント代替として用いるとともに, 細骨材として 用いる可能性を探ることは将来増加するフライアッシュ

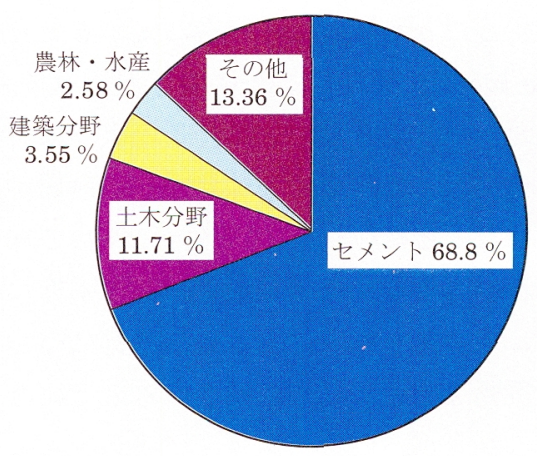

図-2 フライアッシュ (1067万トン $)^{7)}$

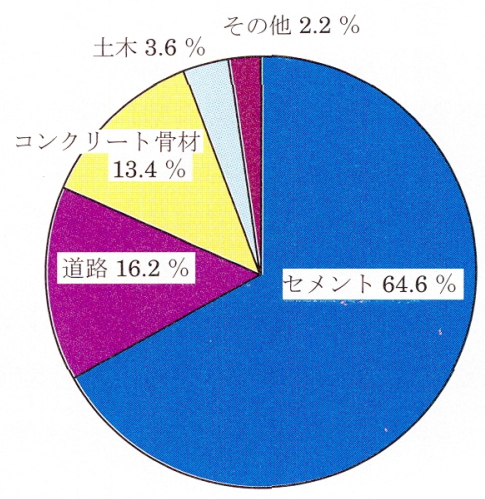

図-3＼cjkstart高炉スラグ (2428 万トン $)^{10)}$ 
の資源化に道を開くあのである。フライアッシュを細骨 材として用いるための技術的検討もなされている9”。

図-3に，日本に抒ける 2006 年度の高炉スラグ利用量 2428 万トンの利用内訳 ${ }^{100}$ を示す。高炉スラグもセメン 卜に多く用いられていることが分かるが，その内訳はセ メントクリンカー代替としての利用が $35 \%$ 程度で, そ の他はセメント原料としての利用である。つまり，高炉 スラグの高炉セメントへの利用拡大を困る余地があると いえる。現在，高炉セメントは，セメント代替として高 炉スラグ 40〜 50\% 程度置換している屯のが多いと考元 られるが，コンクリートの性能やセメント製造における $\mathrm{CO}_{2}$ 排出削減の観点汃ら, 置換率を低減して高炉セメン トの利用範囲を拡大する戦略が成立するかもしれない。

高炉スラグのコンクリート用骨材としての利用は 325 万トン程度である。現在の骨材の利用量が 5 億卜ン程度 であることを考えれば，環境の観点から高炬スラグは骨 材代替ではなくセメント代替として利用することが合理 的であるといえる。

フライアッシュや高炉スラグのような混和材は基本的 に産業副産物であるので，一般に製造に関する負荷は考 慮する必要はないが，それらの微粉化や輸送に関わる環 境負荷は考慮する必要がある。このことは，混和材が産 出される場所から遠い所での利用や輸送手段によっては, セメント代替による環境負荷低減効果が減少することを 意味する。いずれにしても，混和材をセメントや骨材代 替として利用することによって，骨材やセメントクリン カ一製造に必要な原料の保存と $\mathrm{CO}_{2}$ 削減が可能となる。 このような観点から, 従来のコンクリート技術体系の再 構築を目指し，コンクリートの性能に関する基礎的な研 究を早急に進める必要がある。

産業副産物としての各種スラグは，骨材を含む各種用 途に用いられている。スラグ骨材のインベントリデータ は公開されたものがないが，基本的に，副産物として無 害化等の中間処理を行うプロセスまでは副産物発生者が 環境負荷を負うべき範囲であり，その後のリサイクル材 としての資源化と輸送が，スラグ骨材にカウントすべき 環境負荷々なる。産業連関表を用いてスラグ骨材の環境 負荷量を算出した一例を表-1に示す。スラグ骨材の環 境負荷量は天然骨材（砂利）の環境負荷量より小さな值 を示している。さらに，スラグ骨材の利用は資源の有効 利用，天然資源の保護につながることをあわせて考えた とき，積極的にスラグ骨材を活用する方策を検討する必 要性が理解できる。な拉，水砕スラグ，クリンカアッシュ において環境負荷量はゼロとなっているが，これは資源 化工程に含ま机る水砕・冷却の作業が，リサイクル材と して用いず廃棄処分する場合にも必要とする作業である と考え，リサイクル材としての箃密な資源化工程ではな いとみなして環境負荷量に計上していないためである ${ }^{11}$ 。 一方，近年，一般・産業廃棄物を溶融処理することが
表-1 リサイクル材の資源化における単位量あたりの 環境負荷量

\begin{tabular}{|c|c|c|c|}
\hline \multicolumn{2}{|c|}{ リサイクル材 } & $\begin{array}{c}\text { エネルギー消費量 } \\
\text { (単位：Mcal/t) }\end{array}$ & $\begin{array}{c}\mathrm{CO}_{2} \text { 排出量 } \\
\text { (単位: } \mathrm{t}-\mathrm{C} / \mathrm{t} \text { ) }\end{array}$ \\
\hline \multirow{3}{*}{ 製鋼スラグ } & 徐冷スラグ & 12.2 & $9.5 \times 10^{-4}$ \\
\hline & 水砕スラグ & 0.0 & 0 \\
\hline & 転炉スラグ & 11.5 & $7.1 \times 10^{-4}$ \\
\hline \multirow{2}{*}{$\begin{array}{l}\text { 非鉄金属ス } \\
\text { ラグ }\end{array}$} & フェロニッケルスラグ & 13.4 & $7.3 \times 10^{-4}$ \\
\hline & 銅スラグ & 0.1 & $6.8 \times 10^{-6}$ \\
\hline \multirow[t]{2}{*}{ 石炭灰 } & $\begin{array}{l}\text { フライアッシュ } \\
\text { (海砂代替材) }\end{array}$ & 116.8 & $2.3 \times 10^{-2}$ \\
\hline & クリンカアッシュ & 0.0 & 0 \\
\hline \multicolumn{2}{|c|}{ 天然骨材 (砂利) } & 21.0 & $2 \times 10^{-3}$ \\
\hline
\end{tabular}

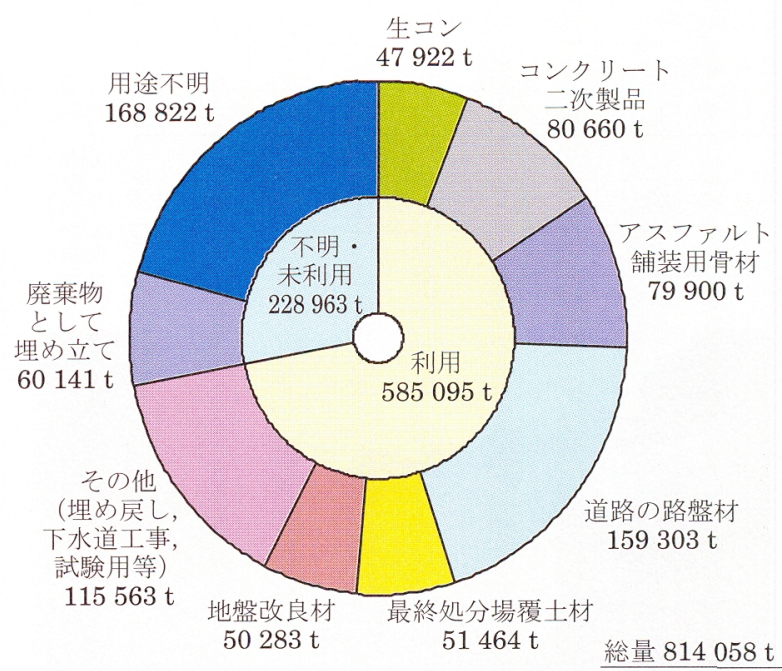

図-4 一般・産業廃棄物溶融スラグの利用内訳

一般的になり, 最終残滓である溶融スラグの処理が重要 な課題として浮上している。これまで溶融処理は, 有害 物の無害化および減容を目的として行われてきており， 溶融スラグをコンクリート用細骨材として用いることを 前提とした処理が行われていない。平成 17 年度を対象 にして香川大学で行った全国の 207 の溶融施設に対する アンケート調査の結果（回答数：169）によれば，7施 設が溶融スラグを生コンクリート用細骨材として利用し ているものの，図-4に示すように，その総量はスラグ 総生産量約 81 万トンの約 $6 \%$ に過ぎない。この内, 7 割弱が香川県豊島不法投棄産業廃棄物等溶融スラグ12)で ある。二次製品を含めたコンクリート用細骨材としての 利用は, 全体産出量の約 $16 \%$ である。豊島産業廃棄物 等の総量は土砂む含めて 60 万トンを超え, 溶融スラグ は 30 万トン程度になると見られている。豊島溶融スラ グは，最初から全量コンクリート用細骨材として利用す ることが決定され，その細骨材としての品質基準は表-2 に示すと括りである。表-3に，2007 年 3 月までの利用 内訳を示す。また，写真-1 は，豊島溶融スラグを細骨 材 30\% 置換して用いた砂防堰堤の例を示す。

廃衰物溶融スラグをコンクリート用細骨材として使用 する場合の環境負荷はどのように考えるべきであろうか。 一般に，廃棄物溶融処理には多くの資源・エネルギーが 
表-2＼cjkstart豊島溶融スラグの品質基準

\begin{tabular}{c|c}
\hline 項目 & 品質基準 \\
\hline 粒度 & $5 \mathrm{~mm}$ オーバーの割合が $0 \%$ であること \\
\hline 磁着物割合 & スラグ中に $1 \%$ 以上の金属鉄分をふくまないこと \\
\hline 形状 & スラグ中に針状物を含まないこよ \\
\hline 絶乾密度 & $2.5 \mathrm{~g} / \mathrm{cm}^{3}$ 以上 \\
\hline 吸水率 & $3 \%$ 以下 \\
\hline アルカリシリカ反応性 & 無害であること \\
\hline
\end{tabular}

表-3 豊島溶融スラグの利用内訳

\begin{tabular}{|c|c|c|}
\hline \multicolumn{2}{|c|}{ レディーミクストコンクリート } & 利用量 $(t)$ \\
\hline 道路構造物 & 擁壁, 側溝, 標識基礎等 & 21600 \\
\hline 河川構造物 & 根継コンクリート, 護床ブロック等 & 21200 \\
\hline 砂防構造物 & 堰堤, 床固め工等 & 13400 \\
\hline 農林構造物 & 擁壁, 側溝等 & 14400 \\
\hline 林務構造物 & 谷止め工 & 7500 \\
\hline \multicolumn{2}{|r|}{ コンクリート二次製品 } & 利用量 $(\mathrm{t})$ \\
\hline 道路・水路製品 & 積ブロック, 張ブロック, U 型トラフ等 & 7900 \\
\hline \multicolumn{2}{|r|}{ 合計 } & 86000 \\
\hline
\end{tabular}

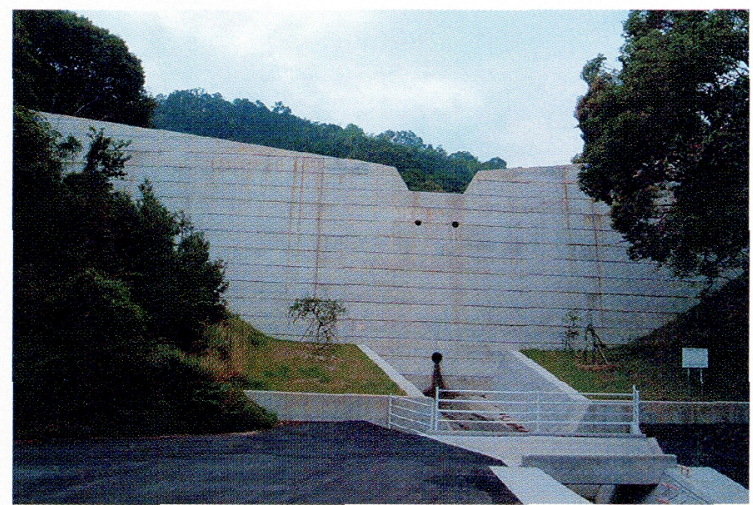

写真-1 豊島溶融スラグを用いた砂防堰堤

必要となる。しかし, 溶融処理は, 廃棄物の減容および ダイオキシンや重金属の安全処理のために行う屯のであ り, 結果として飛灰と溶融スラグが排出される。飛灰か らは更にエネルギーを消費して重金属が回収されるもの の，廃棄物溶融処理からは主要な生産物は無い上考える ことができ，これが他の副産物スラグと異なる点である。 つまり，廃棄物溶融処理で用いられる資源・エネルギー による環境負荷を負わす対象が無いことになる。しかし， 廃棄物溶融スラグに溶融処理により発生する環境負荷を 背負わせてコンクリートの環境負荷を評価することは意 味が無い。溶融処理および輸送等による環境負荷は社会 が負うべきであり，その残滓である溶融スラグのコンク リートへの利用は，溶融スラグの更なる処理に伴う環境 負荷の解消および骨材資源の保存に寄与すると考えるの が合理的である。

\section{4. 環境影響評価システム}

環境影響評価を実際に行い，環境負荷低減を図るため にはそれを促進するシステムが必要となる。そのような システムの1つとして, 国際規格 ISO 14000 シリーズ
があるが，これを建設分野の本業へ適用することは困難 である。なぜなら，これらの規格はもともと工業製品や サービスを対象にしたむのであり，建設会社が ISO 14001 の認証を取得したと言っても，その内容は本業に 直接関係ない部分での環境負荷低減を意味していた。し かし，多くの負荷は建設行為に関わるすべての領域で発 生しており，これを低減しない限り実質的な意味は少な いと言える。このような背景もあり, ISO/TC 59/SC 17 は ISO 15686-6（建築物等の環境配慮手順）や ISO 21930 (建築製品の環境宣言) を制定し，コンクリート に関する規格を扱う ISO/TC 71 には環境規格策定のた めの分科会 SC 8 (Environmental management for concrete and concrete structures）（議長：堺）が設置 された。また，ISO/TC 59/SC 17/WG 5 は，土木を対 象とした環境規格を策定するためにその活動を開始した。 このように，ISO は建設分野における環境負荷低減を 目指した規格策定に向けて着実な歩みを始めたと言える。

一方，日本に抢ける土木分野で，価格之品質の両面で 優れた工事であると同時に環境面や省資源への配慮等, 多様な二ーズを満たした工事が求如られて扮り，これを 実現するためのシステムとして総合評価落札方式 ${ }^{13)}$ が導 入されている。この方式における評価は，例えば次式に よる評価値により落札を決定するものである。

$$
\text { 評価值 }=\frac{\text { 基礎点 }+\alpha}{\text { 入札価格 }}
$$

ここで，基礎点は標準仕様をすべて満足している場合に 100 点を与える。また， $\alpha$ は加算点で技術提案等の得点 である。 $\alpha$ を最大何点にするか，どのような項目を設定 するか, また複数の項目を設定する場合, その重み付け をどうするか等，様々な課題はあるあのの，環境配慮に 対する技術提案を評価するシステムとして積極的な活用 が望まれるが，現時点では環境配慮に関する要件設定は 極めて限定された範囲に留まっている。

このシステムを再生骨材・副産物起源骨材の利用促進 のために利用することができる。例えば，低環境負荷再 生骨材の利用あるいは再生骨材製造およびその利用の全 体システムの低環境負荷化技術の提案や，副産物起源骨 材の高度利用法の提案等を積極的に評価することなどで ある。現行の総合評価落札方式は，入札価格が予定価格 を超えないことが求められるが, 環境技術開発の推進の ために，環境負荷低減技術開発で発生するコストを入札 価格に上乗せしても全体評価值が高くなるシステムの導 入屯考慮する必要があると思われる。

一例として，環境負荷量を加算点に考慮した総合評価 の行い方について, 道路トンネルの二次覆工コンクリー トに再生骨材を利用したケーススタディを以下に示 す ${ }^{14), 15)}$ 。再生骨材はコンクリートの品質を低下させるこ とが懸念されるため, 構造体への利用が進んでいないが, ここでは，天然骨材之同等な品質を有する高品質な再生 


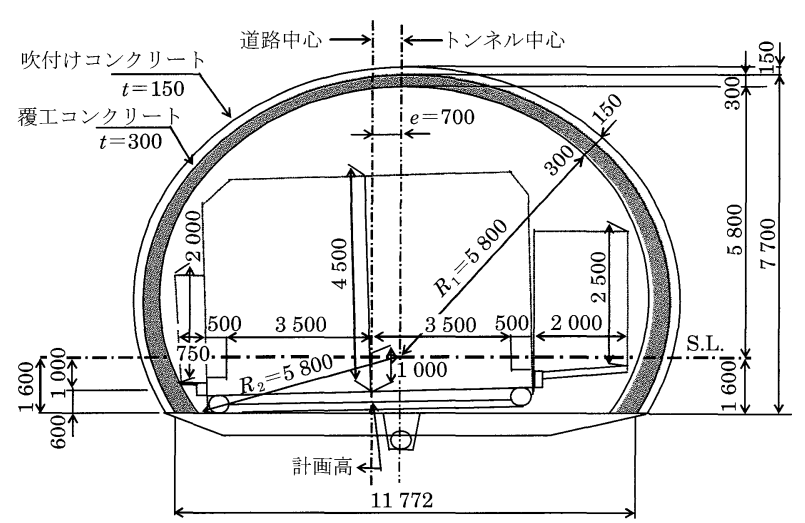

図-5 想定したトンネルの断面図

骨材の利用を想定した。想定したトンネルの断面図を 図-5に示す。トンネル長さとして $500 \mathrm{~m}, 1000 \mathrm{~m}$, $2000 \mathrm{~m}$ の 3 条件を設定し, 使用する骨材の種類を次の 3 ケースについて検討した。

Case 1 : 天然細骨材，天然粗骨材を用いた場合

Case 2 : 天然細骨材, 再生粗骨材（高品質機械すりも み）を用いた場合

Case 3 : 再生細骨材, 再生粗骨材 (いずれも高品質加 熱すりあみ）を用いた場合

紙面の都合上, ここでは詳細な記述は省略する。詳細 は参考文献 14），15）を参照されたい。検討の範囲は, レディーミクストコンクリート工場でコンクリートを製 造し, 型枠としてスライドセントルを用いて二次覆工コ ンクリートを打ち込み，脱型するまでである。

ここでは環境負荷量としてェネルギー投入量, 天然資 源消費量（石油換算，石炭換算，天然ガス，非金属鉱物， 鉄), 廃棄物発生量, 大気排出物質量 $\left(\mathrm{CO}_{2}\right.$ 排出量, $\mathrm{SO}_{\mathrm{x}}$ 排出量, $\mathrm{NO}_{\mathrm{x}}$ 排出量, ばいじん排出量) を求め, これらの数值を用いて LIME（日本版被害算定型影響評 価手法 $)^{16)}$ による統合化を行った。統合化とは，環境に 影響をむたらす様々な要因を自然科学的知見や社会科学 的解析に基づき単一指標化することである。LIME は解 析手法の相違により, 3 種類の単一指標が得られるよう になっているが，統合化 ver.2 による計算結果を例とし

て図-6に示す。

統合化された単一指標では, トンネル長さによらず, Case 2 で值が最む小さく, 次いで Case 1 となってお り, Case 3 は大きな值を示す結果となった。鉱物資源 消費量は Case 1 よりあ Case 2, また Case 2 よりも Case 3 の方が小さくなるあのの, $\mathrm{CO}_{2}$ 排出量等の大気 排出物質量が Case 1 と Case 2 でほとんど同程度である のに対して, Case 3 では極めて大きくなるために，こ のような結果となっている。この結果を用い, Case 1 を標準案と想定した場合の, 総合評価を試みた。ただし， Case 3 では環境負荷量が標準案を上回ってしまうこと から，ここでは Case 2 についてのみ比較検討すること とする。

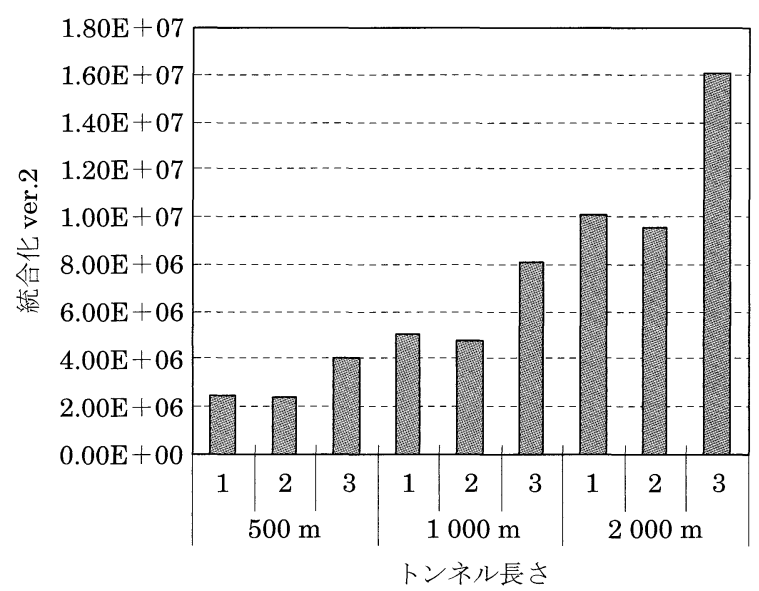

図-6＼cjkstart各ケースにおける単一指標の比較

総合評価に打ける基礎点を 80 点, 加算点を 20 点とし, 加算点は環境負荷量について標準案よりも20\%の低減 が図られた場合に満点が与えられ，それ以下の場合には 低滅率に応じて按分されるとする。コス卜に関しては, Case 1, Case 2 ともに施工費は同じとなるため，材料 費のみで評価することとし, 総合評価管理費を標準仕様 コストの $25 \%$ として試算した。なお，材料費は, Case 1 の場合 1 万円 $/ \mathrm{m}^{3}$, Case 2 の場合, トンネル長さ 500 $\mathrm{m}$ で 1.25 万円 $/ \mathrm{m}^{3}, 1000 \mathrm{~m}$ で 1.10 万円 $/ \mathrm{m}^{3}, 2000 \mathrm{~m}$ で 1.05 万円 $/ \mathrm{m}^{3}$ としている。

試算結果を図-7に示す。トンネル長さが短い場合に は，材料費が高くなることが影響して標準案 (Case 1) の方が評価值は高くなるが，トンネル延長 $2000 \mathrm{~m}$ では Case 2 の方が高い評価值を得ることができる。

この結果から, 総合評価に扔いて環境影響を定量的に 評価することは, 現行のシステムであ十分に可能である と思われる。検討を要するのは, 評価項目としていかな る環境影響要因を利用するかであるが，これは場合によっ て異なったものとなる。例えば上記の例では, 単一指標 化された数值を評価項目として採用したが，この単一指 標が何を意味する值であるかは客観的にイメージしにく い。評価項目を鉱物資源消費量とした場合，環境影響の 中では非常に限定的な評価とはなるが，何を評価してい るかは客観的に非常に明確である。そしてこの鉱物資源 消費量を評価項目とした場合には, Case 1 と比較して Case 2 や Case 3 の評価值が短いトンネル長さであって あ大きな值を示すこととなるであろう。総合評価のよう な場合，何が評価されているのかがわかりやすいことは 非常に重要となる。その点では, 先の鉱物資源消費量や $\mathrm{CO}_{2}$ 排出量などを評価項目とすることは, 第三者に対し ても説明が行いやすい。ただし，その一方で，環境の一 側面しか評価の対象とならないといった欠点を有するこ とも確かである。環境問題はすでに待ったなしの状態に まで来ており，最善の評価方法を十分に検討するよりも， 現在可能な方法で評価の導入を行った上で, 最善策へ近 ゔけていく努力を行うべきではないだろうか。そうする 


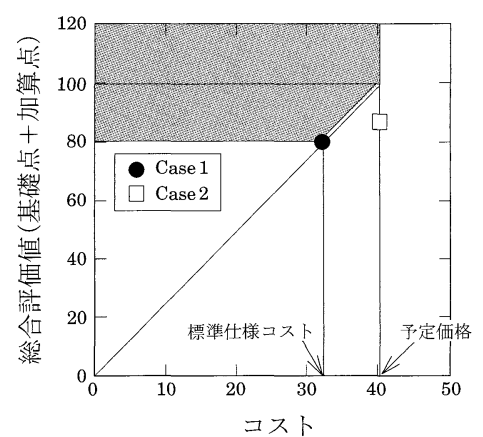

（a）トンネル延長 $500 \mathrm{~m}$ の場合

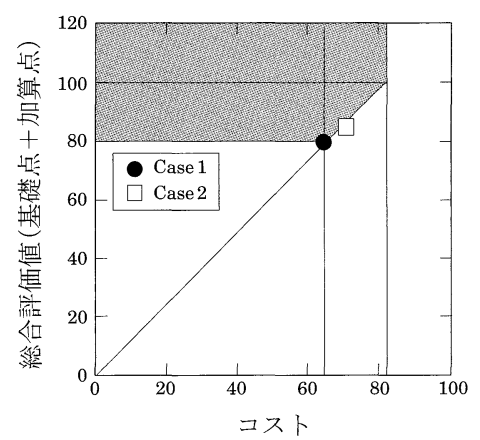

(b) トンネル延長 $1000 \mathrm{~m}$ の場合

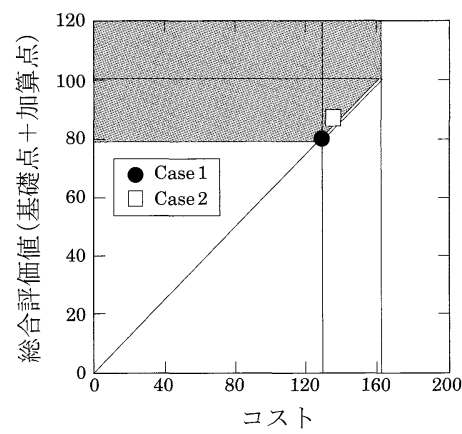

(c) トンネル延長 $2000 \mathrm{~m}$ の場合

\section{図-7 試算結果におけるコストと総合評価値との関係}

ことが，環境を定量的に取り扱うことに対する意識向上 や実際への適用につながっていくものと思われる。

\section{5.おわりに}

コンクリートの骨材は，その容積で 7 割程度を占める。 このことが，コンクリートがこれほどまでに普及した大 きな要因であると言えよう。つまり, 骨材はローカルに 採取でき，しかむその価格が安い。しかし，コンクリー 卜構造物には寿命があるととあに，寿命以外の要因で解 体されることも少なくない。いずれにしてあ，現在ストッ クされているコンクリート構造物拉よびこれから建設さ れるコンクリート構造物は, 将来の資源と見なすべきで ある。そのように考えると，解体コンクリートの再生骨 材製造技術および微粉の合理的な利用技術は極めて重要 となる。現時点に㧈けるこれらの技術は環境の観点から 満足できるレベルにあるとは言えない。近い将来におけ る技術のブレークスルーを期待したい。

土木分野におけるコンクリートには，これまで産業副 産物を積極的に利用してきた。その主眼は省資源にあり，
廃棄物を副産物へ変えることにおいて社会的に大きな貢 献をしてきた。しかし，最近は地球温暖化の観点からこ れらを利用することの意味が急激に高まってきている。 鉄鋼や火力発電の生産量は今後著しく増大することが予 想されており，これらから発生する高炉スラグやフライ アッシュを資源としてだけではなく， $\mathrm{CO}_{2}$ 排出削減のた めに合理的に利用することが喫緊の課題である。セメン トの製造やコンクリートの性能の根本に遡り，環境負荷 低減に向けた検討が必要である。

その他の副産物起源スラグあ, 有用な資源としてのコ ンクリートへの利用を積極的に図っていく必要があるの は当然である。しかし，廃棄物溶融スラグのように必ず しあコンクリート用骨材として用いることを前提として いないために，利用が困難な状況す存在する。このよう な場合，今後，資源として活用できる溶融スラグ製造方 法に切り替えていくことが望まれる。

なお，コンクリートに関わる環境側面の現状と展望に ついては文献 17）を参照されたい。

\section{参考文献}

1）レスター・ブラウン（福岡克也 監訳）：エコ・エコノミー，家の 光協会, 2002

2) http://www.nbm.org/liquid stone/home.html : Liquid stone: New architecture in concrete, National Building Museum

3）土木学会：コンクリート構造物の環境性能照査指針（試案），コ ンクリートライブラリー 125,2005

4）黑田泰弘・橋田 浩・内山 伸・名和洋子・山崎庸行・宮地義明： オンサイト型コンクリート資源循環システム, 清水建設研究報告, 第 79 号, pp.1 10, 2004

5）柳橋邦生：コンクリート用再生骨材製造時の環境負荷と経済性, 建設用原材料，Vol.13，No.1，pp.38４5，2004

6) V. Mohan Malhotra : Reducing $\mathrm{CO}_{2}$ Emissions, The role of fly ash and other supplementary cementitious materials, Concrete International, ACI, pp.42-45, September 2006

7）石炭灰エネルギーセンター：石炭灰全国実態調查（平成 17 年度 実績)

8) P. Jahren : Greener Concrete - What are the options? The $\mathrm{CO}_{2}$ Case, STF22A03610 Report, SINTEF, 2003

9）土木学会四国支部：フライアッシュを細骨材補充混和材として用 いたコンクリートの施工指針（案)，2003

10）鐵鋼スラグ協会：鉄鋼スラグ統計年報（平成 18 年度実績)，平成 19 年 8 月

11）池田秀文・吉村文雄・佐藤 隆・芋野智成：LCA 手法を用いた 港湾構造物の最適化設計, 第 29 回環境システム研究論文発表会 講演集, pp.43〜 49, 2001. 11

12）堺 孝司：エコスラグの有効利用事例一豊島溶融スラグの利用— 特集「エコスラグ」, 産業機械, Vol.686, pp.18〜22, 2007.11

13）国土交通省国土技術政策総合研究所・総合技術政策研究セン夕ー・ 建設マネジメント技術研究室：公共工事発注にあたっての総合評 価落札方式活用ガイド，平成 4 年 2 月

14）土木学会：コンクリートの環境負荷評価（その2）、コンクリー 卜技術シリーズ 62,123 pp.，2004.9

15) Kawai, K., Sugiyama, T., Kobayashi, K., and Sano, S. : Inventory Data and Case Studies for Environmental Performance Evaluation of Concrete Structure Construction, Journal of Advanced Concrete Technology, Vol.3, No.3, pp.435-456, 2005.10 .

16）産業環境管理協会：平成 14 年度新エネルギー・産業技術総合開 発機構委託 製品等ライフサイクル環境影響評価技術開発成果報 告書, 2004

17）堺 孝司：コンクリート構造物の環境負荷低減に向けた技術とシ ステム一現状と展望一，500 号記念特集号＊環境とコンクリート ／Ｉ．総論, コンクリート工学, Vol.45, No.5, pp.4〜15, 2007.5 